\title{
Stock Price Synchronicity and Price Informativeness: Evidence from a regulatory change in
}

\section{the U.S. Banking Industry}

\author{
Pejman Abedifar ${ }^{a, b}$, Kais Bouslah ${ }^{a, 1}$, Yeliangzi Zheng ${ }^{a}$ \\ ${ }^{a}$ Centre for Responsible Banking \& Finance, School of Management, University of St Andrews, UK \\ ${ }^{\mathrm{b}}$ Department of Tehran Institute for Advanced Studies, Khatam University, Tehran, Iran
}

June 15, 2020

\begin{abstract}
Whether return synchronicity is associated with higher or lower stock price informativeness is still an ongoing debate in the academic literature. This paper contributes to this debate by exploiting an exogenous shock, provided by a regulatory change introduced by the Federal Reserve in 2015, and examining its impact on return synchronicity using a sample of U.S. listed bank holding companies (BHCs) operating during the period of 2014: Q3 - 2016: Q2. Applying a regression discontinuity design, we find that return synchronicity of treated BHCs decreases after the regulatory change. This finding suggests that lower return synchronicity represents lower stock price informativeness.
\end{abstract}

JEL Classifications: G14, G21, G28

Keywords: Price Informativeness; Stock Return Synchronicity; Financial Regulation; Bank Opacity

Acknowledgement: This paper was presented at the 2019 Cross Country Perspectives of Finance (CCPF) conferences held in Jinan, China and Mauritius. We would like to thank Sheng Zhao, seminar participants of the CCPF conferences and two anonymous referees for their constructive comments. Any remaining errors are our own.

\footnotetext{
${ }^{1}$ Corresponding author.

E-mail addresses: p.abedifar@teias.institute (P.Abedifar); kbhb@st-andrews.ac.uk (K.Bouslah); yz61@standrews.ac.uk (Y.Zheng).
} 


\section{Introduction}

Banks are inherently more opaque than companies in other industries (Morgan, 2002; Blau, Brough and Griffith, 2017). Existing empirical research has shown that it is difficult for outsiders to valuate banks (Jones, Lee and Yeager, 2012; Flannery, Kwan and Nimalendran, 2013). As a consequence, market discipline presumes to be less effective for banks (Morgan and Stiroh, 2001).

Stock price informativeness is a key concept to better understand the role played by market discipline. The most famous measure of stock price informativeness in literature is stock return synchronicity, which is the co-movement of an individual stock return with the market (e.g., Gul, Kim and Qiu, 2010; An and Zhang, 2013; Jones, Lee and Yeager, 2013). However, whether higher return synchronicity is associated with higher or lower informativeness has been a subject of debate in recent years (e.g., Jin and Myers, 2006; Dasgupta, Gan and Gao, 2010; Xing and Anderson, 2011).

The first theory argues that lower synchronicity represents higher stock price informativeness. Roll (1988) suggests that low stock price synchronicity could be caused by either the incorporation of private information or occasional frenzy (i.e., noise). Inspired by Roll's work, Morck, Yeung and Yu (2000) and Durnev et al. (2003) find that stocks have lower return synchronicity because more firm-specific information is incorporated into stock prices thanks to active informed arbitrageurs. Morck, Yeung and $Y u(2000)$ and Jin and Myers (2006) further find that more difficulties in understanding a firm (e.g., higher opacity) could discourage informed trading by increasing the cost of informed arbitrage, and consequently, prevent the incorporation of firm-specific information into stock prices. Based on the findings, they conclude that price synchronicity is higher when firms are more difficult to be understood, and stock prices are less informative.

However, the second theory advocates a positive relationship between synchronicity and stock price informativeness. Dasgupta, Gan and Gao (2010) propose a theoretical model predicting that price synchronicity increases when a firm is less opaque. They explain that lower opacity can accelerate the incorporation of firm-specific information and reduce idiosyncratic variation. Chan and Chan (2014) find a negative relationship between return synchronicity and the discount of seasoned equity offerings (SEOs). Given that SEO discount is lower when investors face less information asymmetry, they conclude that higher synchronicity indicates higher informativeness. 
We examine whether more opaque banks have lower or higher stock return synchronicity. Banks are usually excluded from the empirical research discussing the relationship between synchronicity and informativeness, because banks are different from non-financial firms in many aspects. However, opacity is more compelling and prevalent in the banking industry and regulations attempt to improve the disclosure quality to alleviate information asymmetry in banking industry (Akhigbe and Martin, 2006; Jirasakuldech et al., 2011). Therefore, we argue that the banking industry and regulatory change that targets information disclosure is an ideal setting for investigating this debate.

To reduce the regulatory burden for small banks, the Fed issued a new Small Bank Holding Company (BHC) Policy Statement in May 2015. With this regulation, the asset threshold for identifying small BHCs was increased from $\$ 500$ million to $\$ 1$ billion. Newly qualified small BHCs can enjoy relatively loose capital and regulatory reporting requirements (The Federal Reserve, 2015). In this paper, we test whether this regulatory change could affect bank synchronicity using a sample of U.S. listed BHCs operating during the period of 2014: Q3 - 2016: Q2. As robustness checks, we use the illiquidity ratio of Amihud (2002) as an alternative trade-based measures of price impact (Kyle, 1985). We find that the synchronicity of treated BHCs is significantly lower than control BHCs after the implementation of the 2015 policy statement, and the illiquidity ratio of treated banks is significantly lower than control BHCs.

This paper contributes to the existing literature. To the best of our knowledge, we test the relationship between stock price synchronicity and informativeness for the first time in the banking industry. Most previous studies examined samples including only non-financial firms (e.g., Dasgupta, Gan and Gao, 2010; Kelly, 2014; Chan and Chan, 2014). Our findings provide further evidence in support of a positive relationship between return synchronicity and price informativeness.

The rest of the paper is organised as follows. Section 2 presents our hypothesis. Section 3 presents the methodology and econometric specifications. Section 4 discusses the data and descriptive statistics. The empirical results are presented in section 5 . Section 6 concludes.

\section{Hypothesis}


Stock prices and information flows have symbiotic relationship and are inseparable in financial markets. An informative stock price is expected to reflect fundamental value and firm-specific information of the company (Jones, Lee and Yeager, 2012; Flannery, Kwan and Nimalendran, 2013). Stock price informativeness is usually measured by stock return synchronicity, however, there is no consensus to date about whether higher return synchronicity is associated with higher or lower informativeness (e.g., Jin and Myers, 2006; Dasgupta, Gan and Gao, 2010). One theory supports the negative relationship between synchronicity and informativeness (e.g., Roll, 1988; Morck, Yeung and Yu, 2000; Durnev et al., 2003; Banerjee, Davis and Gondhi, 2018), while the other theory predicts the positive relationship (e.g., Dasgupta, Gan and Gao, 2010; Chan, Hameed and Kang, 2013; Chan and Chan, 2014; Kan and Gong, 2018; Watanabe, Imhof and Tartaroglu, 2019). Both theories are supported empirically. However, banks are excluded from previous studies.

To examine the relationship between synchronicity and informativeness, we test the impact of the 2015 Small BHC Policy Statement on synchronicity. If higher return synchronicity implies higher (lower) price informativeness, then return synchronicity and bank opacity are negatively (positively) related. This implies that stock return synchronicity of treated banks decreases (increases) after the introduction of the 2015 policy statement. This leads to our hypothesis, stated in its alternative form:

$\mathbf{H}_{1}$ : The introduction of the 2015 Small BHC Policy Statement decreases (or increases) stock return synchronicity of treated banks.

\section{Methodology and Econometric Specifications}

\subsection{Institutional Background}

Drawing lessons from the 2007-2008 financial crisis, the Fed strengthened the supervision on the banking sector. However, concerns about the potential impacts of postDodd-Frank rules and regulations have been arisen in recent years, particularly for small banks (Conference of State Bank Supervisors and Federal Reserve, 2013 and 2017). To relieve regulatory burden for small banks, a new Small Bank Holding Company (BHC) Policy Statement was signed into Public Law 113-250 in December 2014 (The Congress, 2014) and 
was effective in May 2015 (The Federal Reserve, 2015)². With this new regulatory change, the asset threshold for identifying small BHCs increased from $\$ 500$ million (valid from 2006) to \$1 billion. Newly classified small BHCs are exempt from strict capital and reporting requirements.

The BHCs newly classified as small BHCs are exempt from risk-based and leverage capital rules under Basel III, although their affiliated banks are still subjected to the Basel III capital requirements. In addition to the less restrict capital requirement, small BHCs under the Policy Statement enjoy the reduced form of reporting requirement. Medium and large BHCs are required to submit FR Y-9C report quarterly and FR Y-9LP semi-annually. With a length of 60 pages, FR Y-9C is a regulatory report covering financial data of parent companies and their subsidiaries. FR Y-9LP is a parent only regulatory report with a length of 9 pages. However, the qualifying small BHCs are only required to submit FR Y-9SP report semi-annually. FR Y-9SP is an 8-page parent company only financial statement and contains less information than FR Y-9C.

\subsection{Empirical Strategy}

We follow Dechezleprêtre et al., (2016) and use a simple reduced-form regression discontinuity $(\mathrm{RD})^{3}$ equation of the form:

$$
I N F_{i, t}=\alpha_{1, t}+\alpha_{2} \text { Treatment }_{i, 2014}+f_{1, t}\left(\text { Size }_{i, 2014}\right)+\varphi X_{i t}+\varepsilon_{1 i, t}
$$

\footnotetext{
${ }^{2}$ The Policy Statement has been revised three times since 1980. The asset threshold to identify small BHCs was initially set to $\$ 150$ million in 1980. It was increased to $\$ 500$ million in 2006 to address the effects of inflation, bank safety and soundness, and normal asset growth of BHCs (The Federal Reserve, 2006). In 2015, the asset limit was raised to $\$ 1$ billion, and all saving and loan holding companies (SLHCS) with total assets less than \$1 billion had been covered by the Policy Statement since then (The Federal Reserve, 2015). The most recent adjustment was in 2018. In the spirit of the Economic Growth, Regulatory Relief, and Consumer Protection Act (EGRRCPA), the Fed increased the asset threshold to $\$ 3$ billion to further reduce regulatory burden (The Federal Reserve, 2018).

${ }^{3}$ The RD design is valid when banks or their parent companies cannot "precisely manipulate" the running variable (Imbens and Lemieux, 2008; Lee and Lemieux, 2010). The newly qualifying small BHCs (i.e., those becoming small BHCs only under the new asset threshold) could only get benefits from the regulatory change after May 2015 (The Federal Reserve, 2015). However, the capital and reporting exemptions were based on the BHC assets in June 2014, and the Fed first announced the change of asset threshold in December 2014 (The Congress, 2014). That prevented banks' strategic behaviour around the new threshold. Hence, 2015Q3 and afterwards are treated as full policy-on periods. Meanwhile, the small BHC status of a BHC in 2015Q3 and afterwards was based on its financial and operational status in 2014Q2. Using assets in 2014Q2 as the primary running variable could mitigate the concern that there might be endogenous sorting of the affiliated banks across the threshold. An RD design assumes that the distribution of all predetermined variables should not change discontinuously around the threshold (Lee and Lemieux, 2010), therefore, eligibility of small BHC status is as good as randomly assigned it at the cut-off point.
} 
Where $\mathrm{i}$ and $\mathrm{t}$ subscripts represent individual $\mathrm{BHC}$ and time, respectively. $I N F_{i, t}$ is a measure of stock price informativeness. We use polynomials of the running variable, parentBHC asset in 2014Q2 $f_{1, t}\left(\right.$ Size $\left._{i, 2014}\right)$, which can be fallen on either side of the new asset threshold $(\overline{\text { Size }})$. Treatment $t_{i, 2014}$ is a binary dummy taking the value of one if 2014Q2 assets of the parent company of bank $i$ are less than or equal to the asset threshold ( $\$ 1$ billion), and zero otherwise, and it represents the eligibility of the bank i's parent company for the Small BHC Policy Statement. The coefficient $\alpha_{2}$ captures the effect of being below the asset threshold on price informativeness. $X_{i t}$ is a set of control variables which are the determinates of synchronicity highlighted in the literature, and $\varepsilon_{1 i, t}$ is an error term. Standard errors are clustered at the BHC level.

Based on equation (1), we estimate regressions for quarter-by-quarter outcomes. Following Dechezleprêtre et al., (2016), we also run analogous regressions in the pre-policy quarters to assess the validity of the RD design.

\subsection{Measures of Stock Price Informativeness}

\subsubsection{Stock Return Synchronicity}

Stock price synchronicity is measured as the logit transformation of the R-squared statistic from a regression of individual stock return on market return. It is measured for each bank-quarter in the sample. Following the method proposed by Morck, Yeung and Yu (2000), we regress banks' daily returns on daily market returns as follows:

$$
R E T_{i t}=\alpha_{0}+\alpha_{1} \operatorname{MKTRET}_{t}+\varepsilon_{i t}
$$

where $M K T R E T_{t}$ is the day $t$ value-weighted return on NYSE/AMEX/NASDAQ, and $R E T_{i t}$ is the daily stock return of bank $i$.

We run regressions for each bank on a quarterly basis and obtain R-squared statistics $\left(R_{i t}^{2}\right)$ from each estimation. The stock price synchronicity for bank $i$ in quarter $t$ then can be calculated as the log ratio of explained return variance to unexplained return variance:

$$
S Y N_{i t}=\ln \left[R_{i t}^{2} /\left(1-R_{i t}^{2}\right)\right]
$$

\subsubsection{Stock Illiquidity}


As robustness checks, we use the illiquidity ratio of Amihud (2002) ${ }^{4}$ as an alternative measure of price informativeness (Ferreira, Ferreira and Raposo, 2011; Fresard, 2012). The illiquidity ratio (IIliq) is the average of the daily stock's absolute return and its dollar volume (multiplied by $10^{6}$ ) (Fresard, 2012). The variable is calculated as:

$$
\text { Illiq }_{i t}=\frac{1}{D_{i t}} \sum_{\tau=1}^{D_{i t}} \frac{\left|R E T_{i \tau}\right|}{\operatorname{VolD}_{i \tau}},
$$

where $D_{i t}$ is the number of trading days for bank $i$ with valid observations in quarter $t$, $R E T_{i \tau}$ is the daily stock return, and $\operatorname{VolD}_{i \tau}$ is the dollar volume of bank $i$ on day $\tau$.

\subsection{Control Variables}

We first control for bank size (Size ${ }_{i t}$ ) which is measured as the logarithm of bank assets (Hughes, Mester and Moon, 2001). The loan to asset ratio (LoanToAsset ${ }_{i t}$ ) is included because it is difficult for outsiders to value the banks' assets, especially loans (Flannery, Kwan and Nimalendran, 2004; Francis et al., 2015). Bank capitalisation is controlled by the ratio of equity to assets (Equity Ratio $_{i t}$ ). A better capitalised bank receives more monitoring from shareholders, and they suffer less from moral hazard problems (Berger and DeYoung, 1997). Following Thomas (2002) and Bai et al. (2017), we use the market-to-book ratio MTB to control for a bank's growth opportunities, since banks with better growth opportunities could reveal more firm-specific information. Non-performing loans $\left(N P L_{i t}\right)$ are regarded as bank-specific signals of information asymmetry the banking literature (Sarkisyan et al., 2009; Jones, Lee and Yeager, 2013). The return on asset $\left(\mathrm{ROA}_{\mathrm{it}}\right)$ is included to control for profitability (Stiroh and Rumble, 2006).

\section{Data and Descriptive Statistics}

The empirical analysis is conducted on a sample of U.S. listed BHCs operating during the period 2014: Q3 - 2016: Q2. Banks' quarterly financial data and daily market data are extracted from S\&P Global Market Intelligence. Daily market returns are calculated based

\footnotetext{
${ }^{4}$ Stock prices are assumed to efficiently aggregate information from various market participants and hence improve the allocation of resources (Hayek, 1945). The aggregation of information is enabled by the trading activity of diverse speculators who incorporate their private information into market prices via their trades (Kyle, 1985). As in Kyle (1985) and Fresard (2012), the degree to which the price is affected should be positively related to the perceived amount of informed trading on a stock. Therefore, the illiquidity ratio is positively related to the amount of private information incorporated into stock prices (Fernandes and Ferreira, 2008; Fresard, 2012). Thus, higher illiquidity ratio indicates higher stock price informativeness.
} 
on the daily market risk premium from Kenneth R. French's Website ${ }^{5}$. There are 229 BHCs and 2,971 quarter-BHC observations in the final sample ${ }^{6}$.

Table 1B displays the descriptive statistics of bank-level data for the whole sample. The average stock return synchronicity is -3.99 , while the average illiquidity ratio is 0.02 . Compared to stock return synchronicity, the illiquidity ratio shows a lower variation. In addition, the mean book value of assets is $\$ 1.01$ billion, while the maximum of total assets is $\$ 2.00$ billion. On average, the loan-to-asset ratio is $69 \%$, and the equity-to-asset ratio is $11 \%$. The average ratio of non-performing loans to total assets is $2 \%$. The correlations among all independent variables are presented in Table 2 in the Appendix. All correlation coefficients are at an acceptable level suggesting that there is no multicollinearity problem in our regressions.

\section{Empirical Results}

Based on Eq. (1), we examined the impact of the 2015 Small BHC Policy Statement on stock return synchronicity using regression discontinuity (RD) design. Treatment ${ }_{i, 2014}$ is a dummy variable indicating whether the parent $\mathrm{BHCs}^{\prime}$ total assets are below \$1 billion in 2014:Q2. The running variable is the total assets of BHCs in 2014:Q2. Fig. 1 displays the visible discontinuity in stock return synchronicity at the asset threshold. There is clear evidence of a sudden decrease in stock return synchronicity for treated BHCs at the threshold showing the effect of the regulatory change.

Regression results are reported in Table 3. Columns 1-4 show the results for four prepolicy quarters. There is no significant discontinuity in synchronicity at the asset threshold, indicating that there is no pre-policy trend. The coefficients in columns 5 and 6 are negative and significant. This implies that BHCs whose total assets are below the threshold had significantly lower stock return synchronicity than BHCs whose total assets are above the threshold. This finding suggests a positive relationship between informativeness and synchronicity.

\footnotetext{
${ }^{5} \mathrm{http} / / / \mathrm{mba}$.tuck.dartmouth.edu/pages/faculty/ken.french/data_library.html\#Research

${ }^{6}$ We exclude several banks based on exclusion criteria applied by the existing literature (Jones, Lee and Yeager, 2013; Fosu et al., 2018). First, we remove banks operating less than three consecutive quarters. Second, we exclude banks with available daily observations fewer than 26 in one quarter when calculating return synchronicity. Finally, considering the comparability of the treated group and control group, BHCs with total consolidated assets more than $\$ 2$ billion are excluded. Following Jones, Lee and Yeager (2013) and Fosu et al. (2018), all balance sheet items are presented as end-of-quarter amounts. All quarterly data are winsorized at the 1st and 99th percentiles.
} 
As robustness checks, we use the illiquidity ratio (Illiq) of Amihud (2002) as an alternative trade-based measure of price informativeness. .Columns 2 to 4 of Table 4 show no significant discontinuity in Illiq at the asset threshold in the pre-policy period. However, the coefficients in columns 5 to 7 are negative and significant, indicating a significant decrease in Illiq in the post-policy period. Overall, we find that more opaque BHCs, those with total assets below the threshold, had significantly lower stock return synchronicity and Illiq in the post-policy period. This finding implies a positive relationship between price informativeness and return synchronicity.

\section{Conclusion}

Whether return synchronicity is associated with higher or lower stock price informativeness is still an ongoing debate in the academic literature. In this paper, we explore this relationship in the banking industry. In particular, we examine the link between bank opacity and stock return synchronicity. A positive (negative) link between bank opacity and return synchronicity would support a negative (positive) relationship between return synchronicity and informativeness.

We exploit an exogenous shock provided by a regulatory change. The 2015 Small BHC Policy Statement reduces regulatory burden for small banks by decreasing the quantity and quality of regulatory reporting. We test whether the policy affects stock return synchronicity using a regression discontinuity design.

We find that stock return synchronicity of the treated BHCs decreases after the implementation of the 2015 Small BHC Policy Statement. This finding suggests that lower return synchronicity represents lower stock price informativeness. Our results have important implications for policy makers. Although this regulation helps reduce regulatory burden, those affected BHCs became more opaque for investors, which may impede market discipline. 


\section{References}

Akhigbe, A. and Martin, A.D., 2006. Valuation impact of Sarbanes-Oxley: Evidence from disclosure and governance within the financial services industry. Journal of Banking and Finance, 30(3), pp.989-1006.

Amihud, Y., 2002. Illiquidity and stock returns: cross-section and time-series effects. Journal of Financial Markets, 5(1), pp.31-56.

An, H. and Zhang, T., 2013. Stock price synchronicity, crash risk, and institutional investors. Journal of Corporate Finance, 21(1), pp.1-15.

Bai, X., Hu, N., Liu, L. and Zhu, L., 2017. Credit derivatives and stock return synchronicity. Journal of Financial Stability, 28, pp.79-90.

Banerjee, S., Davis, J. and Gondhi, N., 2018. When transparency improves, must prices reflect fundamentals better? Review of Financial Studies, 31(6), pp.2377-2414.

Berger, A.N. and DeYoung, R., 1997. Problem loans and cost efficiency in commercial banks. Journal of Banking and Finance, 21(6), pp.849-870.

Blau, B.M., Brough, T.J. and Griffith, T.G., 2017. Bank opacity and the efficiency of stock prices. Journal of Banking and Finance, 76, pp.32-47.

Chan, K. and Chan, Y.C., 2014. Price informativeness and stock return synchronicity: Evidence from the pricing of seasoned equity offerings. Journal of Financial Economics, 114(1), pp.36-53.

Chan, K., Hameed, A. and Kang, W., 2013. Stock price synchronicity and liquidity. Journal of Financial Markets, 16(3), pp.414-438.

Dasgupta, S., Gan, J. and Gao, N., 2010. Transparency, price informativeness, and stock return synchronicity: Theory and evidence. Journal of Financial and Quantitative Analysis, 45(5), pp.1189-1220.

Dechezleprêtre, A., Einiö, E., Martin, R., Nguyen, K-T., Van Reenen, J., 2016. Do tax incentives for research increase firm innovation ?An RD Design for R\&D. NBER Working Paper No. 22405.

Durnev, A., Morck, R., Yeung, B. and Zarowin, P., 2003. Does Greater Firm-Specific Return Variation Mean More or Less Informed Stock Pricing? Journal of Accounting Research, 41(5), pp.797-836.

Fernandes, N. and Ferreira, M.A., 2008. Does international cross-listing improve the information environment. Journal of Financial Economics.

Ferreira, D., Ferreira, M.A. and Raposo, C.C., 2011. Board structure and price informativeness. Journal of Financial Economics, 99(3), pp.523-545.

Flannery, M.J., Kwan, S.H. and Nimalendran, M., 2004. Market evidence on the opaqueness of banking firms' assets. Journal of Financial Economics, 71(3), pp.419-460.

Flannery, M.J., Kwan, S.H. and Nimalendran, M., 2013. The 2007-2009 financial crisis and bank opaqueness. Journal of Financial Intermediation, 22(1), pp.55-84.

Fosu, S., Danso, A., Agyei-Boapeah, H., Ntim, C.G. and Murinde, V., 2018. How does banking market power affect bank opacity? Evidence from analysts' forecasts. International Review of Financial Analysis, 60(May), pp.38-52.

Francis, B.B., Hasan, I., Song, L. and Yeung, B., 2015. What determines bank-specific variations in bank stock returns? Global evidence. Journal of Financial Intermediation, 24(3), pp.312-324.

Fresard, L., 2012. Cash savings and stock price informativeness. Review of Finance, 16(4), pp.985-1012. 
Gul, F.A., Kim, J.B. and Qiu, A.A., 2010. Ownership concentration, foreign shareholding, audit quality, and stock price synchronicity: Evidence from China. Journal of Financial Economics, 95(3), pp.425-442.

Hayek, F., 1945. The use of knowledge in society. In: The American Economic Review. Cambridge: American Economic Association, pp.519-530.

Hughes, J.P., Mester, L.J. and Moon, C.G., 2001. Are scale economies in banking elusive or illusive?: Evidence obtained by incorporating capital structure and risk-taking into models of bank production. Journal of Banking and Finance.

Imbens, G.W. and Lemieux, T., 2008. Regression discontinuity designs : A guide to practice. Journal of Econometrics, 142, pp.615-635.

Jin, L. and Myers, S.C., 2006. R2around the world: New theory and new tests. Journal of Financial Economics, 79(2), pp.257-292.

Jirasakuldech, B., Dudney, D.M., Zorn, T.S. and Geppert, J.M., 2011. Financial disclosure, investor protection and stock market behavior: An international comparison. Review of Quantitative Finance and Accounting, 37(2), pp.181-205.

Jones, J.S., Lee, W.Y. and Yeager, T.J., 2012. Opaque banks, price discovery, and financial instability. Journal of Financial Intermediation, 21(3), pp.383-408.

Jones, J.S., Lee, W.Y. and Yeager, T.J., 2013. Valuation and systemic risk consequences of bank opacity. Journal of Banking and Finance, 37(3), pp.693-706.

Kan, S. and Gong, S., 2018. Does High Stock Return Synchronicity Indicate High or Low Price Informativeness? Evidence from a Regulatory Experiment. International Review of Finance, 18(4), pp.523-546.

Kelly, P.J., 2014. Information Efficiency and Firm-Specific Return Variation. The Quarterly Journal of Finance, 04(04).

Kyle, A.S., 1985. Continuous Auctions and Insider Trading. Econometrica.

Lee, D.S. and Lemieux, T., 2010. Regression Discontinuity Designs in Economics. Journal of Economic Literature, 48, pp.281-355.

Morck, R., Yeung, B.Y. and Yu, W., 2000. The Information Content of Stock Markets: Why Do Emerging Markets Have Synchronous Stock Price Movements? Journal of Financial Economics, 58(1-2), pp.215-260.

Morgan, D.P., 2002. Rating banks: Risk and uncertainty in an opque industry. American Economic Review, 92(4), pp.874-888.

Morgan, D.P. and Stiroh, K.J., 2001. Market Discipline of Banks: The Asset Test. Journal of Financial Services Research, 20(2-3), pp.195-208.

Roll, R., 1988. R^2. The Journal of Finance, 43(3), pp.541-566.

Sarkisyan, A., Casu, B., Clare, A. and Thomas, S., 2009. Securitization and Bank Performance. Journal of Money, Credit and Banking, 8(45), pp.1617-1658.

Stiroh, K.J. and Rumble, A., 2006. The dark side of diversification: The case of US financial holding companies. Journal of Banking and Finance, 30(8), pp.2131-2161.

The Congress, 2014. Public Law 113-250. [ebook] pp.1-2. Available at: <https://www.congress.gov/113/plaws/publ250/PLAW-113publ250.pdf> [Accessed 13 June 2020].

The Federal Reserve, 2006. Federal Register. [ebook] pp.9897-9903. Available at: <https://www.federalregister.gov/documents/2006/02/28/06-1837/capital-adequacyguidelines-for-bank-holding-companies-small-bank-holding-company-policy-statement> [Accessed 13 June 2020]. 
The Federal Reserve, 2015. Federal Register. [ebook] pp.20153-20158. Available at: <https://www.govinfo.gov/content/pkg/FR-2015-04-15/pdf/2015-08513.pdf> [Accessed 13 June 2020].

The Federal Reserve, 2018. Federal Register. [ebook] pp.44195-44199. Available at: <https://www.federalreserve.gov/newsevents/pressreleases/files/2018-18756.pdf> [Accessed 13 June 2020].

Thomas, S., 2002. Firm diversification and asymmetric information: Evidence from analysts' forecasts and earnings announcements. Journal of Financial Economics, 64(3), pp.373396.

Watanabe, O. V., Imhof, M.J. and Tartaroglu, S., 2019. Transparency Regulation and Stock Price Informativeness: Evidence from the European Union's Transparency Directive. Journal of International Accounting Research, 18(2), pp.89-113.

Xing, X. and Anderson, R., 2011. Stock price synchronicity and public firm-specific information. Journal of Financial Markets, 14(2), pp.259-276.

\section{Appendix}

Figure 1: Discontinuity in average synchronicity over 2015:Q3-2016:Q4

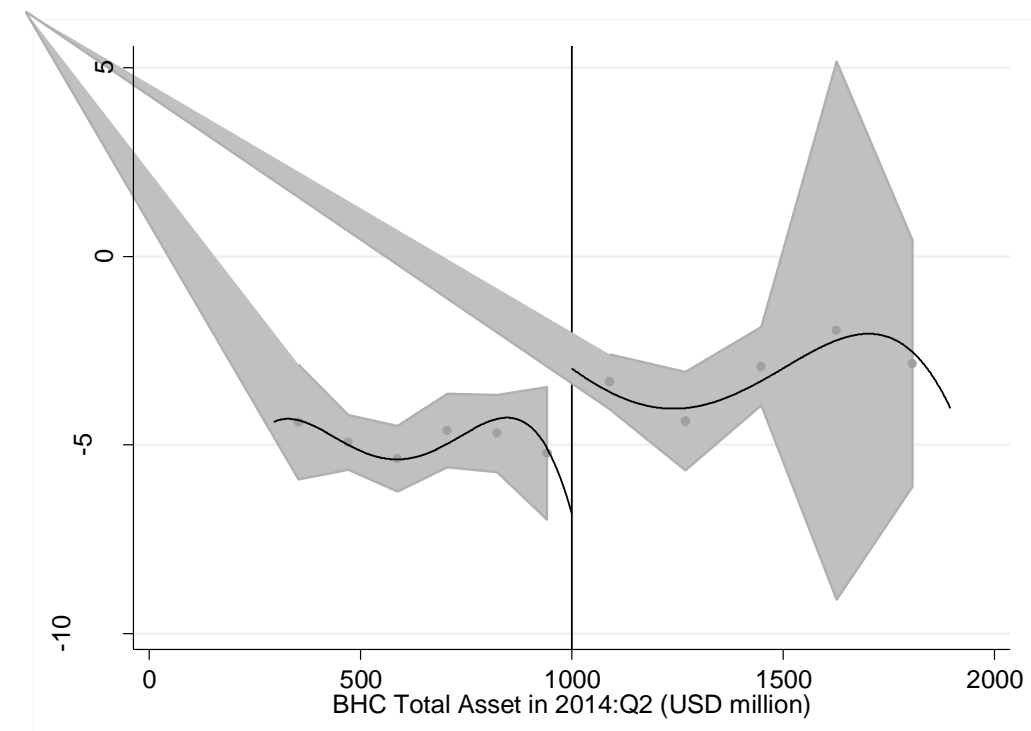

Note: The figure corresponds to the baseline RD Design regression based on equation (1). The dependent variable is the average synchronicity over 2015:Q3-2016:Q2. The running variable is the total assets of BHCs in 2014:Q2 with an asset threshold of $\$ 1$ billion. For each side of the threshold, fourth-order polynomials of the running variable are controlled separately. 
Table 1: Variables description and sample statistics: 2009-2018 (Annual)

Panel A: Description of variables

\begin{tabular}{|c|c|c|c|c|c|c|}
\hline Variables & \multicolumn{6}{|l|}{ Description } \\
\hline SYN & \multicolumn{6}{|c|}{$\begin{array}{l}\text { Stock return synchronicity, a measure of stock price informativeness estimated from the } \\
\text { market model. }\end{array}$} \\
\hline Illiq & \multicolumn{6}{|c|}{ The illiquidity ratio of Amihud (2002) } \\
\hline ROA & \multicolumn{6}{|l|}{ The return on assets. } \\
\hline LnAsset & \multicolumn{6}{|c|}{ The logarithm of the book value of bank asset. } \\
\hline LoanToAsset & \multicolumn{6}{|c|}{ The ratio of bank loans to total assets. } \\
\hline EquityRatio & \multicolumn{6}{|c|}{ The ratio of equity to total assets. } \\
\hline MTB & \multicolumn{6}{|c|}{ The ratio of the market value of equity to the book value of equity. } \\
\hline NPL & \multicolumn{6}{|c|}{ Non-performing loans scaled by total loans. } \\
\hline \multicolumn{7}{|c|}{ Panel B: Sample statistics: 2014:Q3-2016:Q2 (Quarterly) } \\
\hline Variable & Obs & Mean & Median & Std.Dev. & Min & Max \\
\hline SYN & 2,971 & -3.99 & -3.71 & 2.32 & -11.76 & 0.48 \\
\hline Illiq & 2,971 & 0.02 & 0.01 & 0.07 & 0.00 & 0.88 \\
\hline ROA & 2,971 & 0.79 & 0.83 & 0.50 & -2.50 & 2.23 \\
\hline Asset (billion dollars) & 2,971 & 1.01 & 0.97 & 3.23 & 0.16 & 2.00 \\
\hline LoanToAsset & 2,971 & 0.69 & 0.70 & 0.11 & 0.27 & 0.88 \\
\hline EquityRatio & 2,971 & 0.11 & 0.10 & 0.03 & 0.05 & 0.21 \\
\hline MTB & 2,971 & 1.18 & 1.05 & 0.35 & 0.30 & 2.64 \\
\hline NPL & 2,971 & 0.02 & 0.02 & 0.02 & 0.00 & 0.15 \\
\hline
\end{tabular}

Table 2: Pairwise correlations matrix for all explanatory variables

\begin{tabular}{lcccccc}
\hline Variables & $(1)$ & $(2)$ & $(3)$ & $(4)$ & $(5)$ & $(6)$ \\
\hline (1) LnAsset & 1.000 & & & & & \\
(2) ROA & -0.010 & 1.000 & & & & \\
(3) LoanToAsset & -0.000 & 0.016 & 1.000 & & & \\
(4) EquityRatio & 0.000 & $0.192^{*}$ & -0.001 & 1.000 & & \\
(5) MTB & -0.000 & 0.175 & 0.091 & -0.164 & 1.000 & \\
(6) NPL & -0.000 & $-0.207^{*}$ & -0.131 & 0.077 & $-0.274^{*}$ & 1.000 \\
\hline
\end{tabular}

Note: ${ }^{*}$ significant at $1 \%$ level. 
Table 3: Regression discontinuity of the Small BHC Policy Statement on stock return synchronicity

\begin{tabular}{|c|c|c|c|c|c|c|c|c|}
\hline \multirow{3}{*}{ Dependent variable } & (1) & $(2)$ & ( 3 ) & (4) & ( 5 ) & (6) & $(7)$ & $(8)$ \\
\hline & \multicolumn{8}{|c|}{ Synchronicity (SYN) } \\
\hline & \multicolumn{4}{|c|}{ Before (pre-policy) } & \multicolumn{4}{|c|}{ After (post-policy) } \\
\hline Quarter & 2014Q3 & $2014 Q 4$ & $2015 Q 1$ & $2015 Q 2$ & $2015 Q 3$ & $2015 Q 4$ & $2016 Q 1$ & $2016 Q 2$ \\
\hline Below-asset-threshold indicator (in 2014Q2) & $\begin{array}{l}0.0882 \\
(2.711)\end{array}$ & $\begin{array}{l}-1.466 \\
(1.477)\end{array}$ & $\begin{array}{l}-2.071 \\
(1.301)\end{array}$ & $\begin{array}{c}0.341 \\
(0.986)\end{array}$ & $\begin{array}{l}-2.816^{*} \\
(1.663)\end{array}$ & $\begin{array}{c}-2.235^{* *} \\
(1.002)\end{array}$ & $\begin{array}{c}1.076 \\
(0.917)\end{array}$ & $\begin{array}{c}1.085 \\
(1.417)\end{array}$ \\
\hline $\mathrm{BHCS}$ & 133 & 126 & 134 & 133 & 130 & 120 & 118 & 126 \\
\hline
\end{tabular}

Note: ${ }^{* *}$ significant at $1 \%$ level, ${ }^{* *} 5 \%$ level, $* 10 \%$ level. OLS estimates based on the RD Design. The running variable is total assets in $2014 Q 2$ with a threshold of $\$ 1$ billion. The sample includes firms with total assets in 2014Q2 below and above the cut-off (i.e. below $\$ 2$ billion). Controls for first order polynomials of the running variable separately for each side of the threshold are included. Robust standard errors are in brackets. 
Table 4: Regression discontinuity of the Small BHC Policy Statement on stock illiquidity

\begin{tabular}{|c|c|c|c|c|c|c|c|c|}
\hline \multirow{3}{*}{ Dependent variable } & (1) & ( 2 ) & ( 3 ) & (4) & $(5)$ & (6) & $(7)$ & $(8)$ \\
\hline & \multicolumn{8}{|c|}{ Illiquidity (IIliq) } \\
\hline & \multicolumn{4}{|c|}{ Before (pre-policy) } & \multicolumn{4}{|c|}{ After (post-policy) } \\
\hline Quarter & $2014 Q 3$ & $2014 Q 4$ & $2015 Q 1$ & $2015 Q 2$ & $2015 Q 3$ & $2015 Q 4$ & $2016 Q 1$ & $2016 Q 2$ \\
\hline Below-asset-threshold indicator (in 2014Q2) & $\begin{array}{c}-0.013^{* * *} \\
(0.004)\end{array}$ & $\begin{array}{c}0.005 \\
(0.008)\end{array}$ & $\begin{array}{c}0.010 \\
(0.007)\end{array}$ & $\begin{array}{l}0.0033 \\
(0.007)\end{array}$ & $\begin{array}{c}-0.011^{* *} \\
(0.005)\end{array}$ & $\begin{array}{l}-0.011^{*} \\
(0.006)\end{array}$ & $\begin{array}{c}-0.016 * * \\
(0.008)\end{array}$ & $\begin{array}{l}-0.004 \\
(0.004)\end{array}$ \\
\hline $\mathrm{BHCS}$ & 133 & 126 & 134 & 133 & 130 & 120 & 118 & 126 \\
\hline
\end{tabular}

Note: ${ }^{* *}$ significant at $1 \%$ level, ${ }^{* *} 5 \%$ level, $* 10 \%$ level. OLS estimates based on the RD Design. The running variable is total assets in $2014 Q 2$ with a threshold of $\$ 1$ billion. The sample includes firms with total assets in $2014 Q 2$ below and above the cut-off (i.e. below $\$ 2$ billion). Controls for first order polynomials of the running variable separately for each side of the threshold are included. Robust standard errors are in brackets. 